\title{
Towards an Online Searchable Bibliographic Database for Ismā'il Studies
}

\author{
by Nawazali Alibhai Jiwa
}

\section{Abstract}

Research in the field of Ismā îlī Studies has increased exponentially during the last decades. However, all of the existing bibliographies in the field are print-based, which lack the efficient and effective searchability offered by online bibliographic databases. This paper explores some ideas towards creating an ideal online searchable database dedicated exclusively to Ismā îli Studies. It covers elements of an ideal database such as search features, subject headings, linking, metadata, abstracting, and indexing. Moreover, it provides the rationale for a specialized database, as opposed to using multi-disciplinary or interdisciplinary databases to conduct research in Ismā $\mathbf{i} l \overline{1}$ Studies. The database can serve as a model to implement a similar specialized database for other areas of research within and beyond theological and religious studies.

\section{Introduction and Context}

The amount of research conducted in Ismā ${ }^{\prime} \mathrm{il}$ Studies ${ }^{1}$ has increased exponentially during the last few decades. This is attested to by the number of works cited by the existing bibliographies in the field. However, all of these bibliographies are print-based and by their nature lack the searchability and currency offered by online databases. This paper explores and makes a case for why it is crucial to build an online database dedicated exclusively to Ismā ìlī Studies. After establishing its purpose and scope, it focuses on the content and functional requirements of such a database. The former covers the specific bibliographic sources and methods that need to be utilized in order to extract the data. The latter entails a proposal of features to enhance the searchability of that data. Particular attention is paid to the role of subject indexing and metadata in meeting this objective. Finally, this paper addresses the necessity of exclusivity, as well as identifies what types of resources are required to build and maintain the database.

This paper concentrates on secondary sources in Ismā ìlī Studies though most of the discussion also has wider application to primary sources. The first major book-length bibliography of secondary sources was Nagib Tajdin's $A$ Bibliography of Ismailism, published in 1985. ${ }^{2}$ This was followed by Farhad Daftary's Ismā'ìlì Literature: A Bibliography of Sources and Studies, published in $2004 .^{3}$ In 2013, the present bibliographer published a compilation of sources omitted by Tajdin and Daftary within certain limits, hereafter referred to as the Addenda.$^{4}$ All of these bibliographies are print-based which in and of itself is already problematic. As Carol Hetherington explains:

Print bibliographies are inevitably imprisoned within limits of space, time and format. They are "finished" products that must be replaced with a new, updated finished product whenever additions or corrections need to be made. ${ }^{5}$

\footnotetext{
${ }^{1}$ For an extensive survey of the field, see Farhad Daftary, Ismä 'ìlī Literature: A Bibliography of Sources and Studies (London: I.B. Tauris in association with The Institute of Ismaili Studies, 2004). See further, Khalil Andani, "A Survey of Ismaili Studies Part 1: Early Ismailism and Fatimid Ismailism," Religion Compass 10, no. 8 (2016): 191-206; and "A Survey of Ismaili Studies Part 2: Post-Fatimid and Modern Ismailism," Religion Compass 10, no. 11 (2016): 269-82.

${ }^{2}$ Nagib Tajdin, A Bibliography of Ismailism (Delmar, NY: Caravan Books, 1985).

${ }^{3}$ Daftary, Ismä 'ìlì Literature.

${ }^{4}$ Nawazali A. Jiwa, "Addenda to Secondary Sources in Ismā 'îli Studies: The Case of the Omissions," MELA Notes: Journal of Middle Eastern Librarianship 86 (2013): 20-101.

5 Carol Hetherington, "Setting the Record Straight: Bibliography and Australian Literature," Australian Literary Studies 21 , no. 2 (2003): 199.
}

Nawazali A. Jiwa is a graduate of the School of Library and Information Studies (University of Alberta) and has a special interest in Islamic and Ismaili Studies librarianship. 
Just such a point is made in a review of Daftary's book by Moojan Momen, who states:

If I were a scholar wanting to locate primary and secondary material by both Ismā îlīis and non-Ismā îlīs on, let us say, Ismā 'ìli cosmology or the Ismā îli interpretation of the Qur' an (ta'wì $)$, I would not find this book particularly useful since, as a result of ... [the] lack of a subject index, I would have to read through the entire book to find what I want. ${ }^{6}$

\section{Purpose and Scope}

The benefits of a database dedicated to Ismā îli Studies are immediately apparent. Its purpose is twofold: first, to create an organized central resource of all available bibliographic data in Ismā 'îlì Studies, and, second, to facilitate ease, accuracy, and speed of search and retrieval of that data. The database's scope will be wide-ranging and will encompass all aspects of the field. The intended audience will include students, scholars, and specialists, along with research librarians.

Types of bibliographical material included will be books, book chapters, book reviews, scholarly journal and periodical articles, articles in encyclopedias and other works of reference, theses, dissertations, and scholarly online sources. Date coverage will include all secondary sources published to the present day. In addition, it will cover materials in all languages, especially South Asian languages which have been neglected in the existing bibliographies.

\section{Data Extraction}

The data contained in the existing print bibliographies will form one part of the content of such a database. The other part of the content will require an update of the literature from 2004 to the present (with omissions from previous years). The Addenda identifies three broad methods to gather this additional bibliographic data. ${ }^{7}$ These are

1. A systematic and thorough search of Online Public Access Catalogs (OPACs), academic and specialized databases, digital libraries and repositories, and the Internet; ${ }^{8}$

2. Chaining, which entails the identification of seminal or "seed" studies and tracing the sources cited therein. These sources, in turn, cite further studies which are also sought and so on until the chain terminates. Chaining also entails the scrutiny of studies that cite the seed document (also known as "forward chaining");

3. Requesting select members of the "invisible college" to share their bibliographic data. LIS literature employs the term to describe "[a] loosely defined unofficial network of scholars, all working on similar research questions, who become familiar with each other's research through conference attendance, shared research interests, publications, listservs, web pages, and other informal avenues."

In recent years, the library landscape has witnessed a rise in Discovery Services,

systems that harvest and pre-index a wide variety of library content from separate sources ..., build one giant index of all that content, and provide near instance, relevancy ranked results through one search box. ${ }^{10}$

This "Google Model" is offered by OCLC WorldCat Discovery Services, EBSCO Discovery Service (EDS), and ProQuest Summon, amongst others. Though these vendors were included in the Addenda's table of resources, Discovery Services as separate entities need to be added to this list. Also to be added are academic network sites such as ResearchGate and Mendeley (Academia.edu being included in the original list).

\footnotetext{
${ }^{6}$ Moojan Momen, Review of Ismaili Literature: A Bibliography of Sources and Studies, by Farhad Daftary, in Islam and ChristianMuslim Relations 16, no. 4 (2005): 434.

${ }^{7}$ N. A. Jiwa, 23-26.

${ }^{8}$ This method is accompanied by a table showing some of the different types of resources consulted.

${ }^{9}$ Leslie F. Stebbins, Student Guide to Research in the Digital Age: How to Locate and Evaluate Information Sources (Westport, CT: Libraries Unlimited, 2006), 182.

${ }^{10}$ Suzanne S. Bell, Librarian's Guide to Online Searching: Cultivating Database Skills for Research and Instruction, 4th ed. (Santa Barbara, CA: Libraries Unlimited, 2015), 7.
} 


\section{Searchability}

The following section identifies the features that the ideal database will have in order to enhance its searchability. These features are considered standard in library databases, and the description of each is meant to be illustrative of how they would operate on this group of sources.

\section{Field Searching}

Field Searching allows a user to restrict a search to a particular field, the most common ones being author, title, and date. Assume a user is trying to find an item with a keyword search on the term "Muhammad" in the title. Without limiting it to the title field, the search will retrieve a significant amount of irrelevant results because many of the records list the term "Muhammad" as part of an author's name.

\section{Phrase Searching}

Phrase Searching refers to looking for two or more words in a specific order. This is executed by enclosing the phrase in quotation marks, as in "Old Man of the Mountain" or its various renderings such as "Vetulus de Montanis," "Senex de Monte," and "Shaykh al-Jabal." 11 Without the quotation marks, the search will retrieve records that contain the terms but not necessarily as an exact phrase.

\section{Truncation}

Truncation, also known as stemming, enables the user to search for a word and all of the possible variants of that word. It is especially useful for searching a word across different languages. For example, inserting a truncation symbol (commonly an asterisk *) at the end of the word Fātimid* will retrieve some of the following variants:

- Fatimide

- Fatimiden

- Fatimides

- Fatimidi

- Fatimids

\section{Wildcards}

Wildcards enable the user to search for a word that may have multiple spellings but still retains the same meaning. It is placed within a word and is commonly represented by a question mark (?). For example, wom?n will pull up both of these titles: "A Dawoodi Bohra Woman's Experience of Arranged Marriage"12 and "Leaving My Mother's House: Khoja Ismaili Women and University."13

\section{Limiters}

The implementation of limiters allows for more specific search results by adding certain criteria. The most common criteria include:

Limit by publication type: Book, book review, scholarly journal article, encyclopedia entry, dissertation, etc.

Limit by publication language: All languages; English only; selected language(s) only, for example, Arabic and Persian.

\footnotetext{
${ }^{11}$ The title "Shaykh al-Jabal" is a later Arabic translation from the Western forms. See Jerzy Hauziński, "On the Titles of the Ismā îlì-Nizārī Leaders in the Alamūt Period," Folia Orientalia 49 (2012): 238.

${ }^{12}$ Tasneem Arastu, “A Dawoodi Bohra Woman's Experience of Arranged Marriage," Master's thesis, Michigan School of Professional Psychology, 2009.

${ }^{13}$ Saira Jamal Sabzaali, "Leaving My Mother's House: Khoja Ismaili Women and University," PhD diss., Institute of Transpersonal Psychology, 2007.
} 
Limit by publication date: Before or after a certain date; date range, for example, 2004-2018, and further by ascending or descending order.

Limit by publication author: Display of authors after a search ranked by the number of citations attributed to a particular author on a particular topic.

Limit by publication subject: Suggestion of subject/topic areas after a search usually displayed on the sidebar.

Limit by peer review: Peer review is intended to improve the quality control of research but the process is not without criticism. However, there is a strong consensus in academia that the benefits outweigh the disadvantages. ${ }^{14}$ For the purposes of the database, each item that has undergone the process will be readily identified. This is another instance of an electronic bibliography enhancing the usefulness of the existing (print-based) bibliographies in this subject area that do not indicate peer-reviewed items.

\section{Boolean Operators}

The database will employ Boolean operators to connect search terms together to either broaden or narrow a search.

\section{Keyword Search (Free-Text Search)}

A keyword search looks for the specified word or words anywhere in the record. This can be an advantage or a drawback, depending on the purpose of the user. For example, a keyword search on the term "Assassins"15 will retrieve a copious amount of results whereas a search on the term Guptis (secret or hidden ones) ${ }^{16}$ will retrieve only a handful of results as there is not much written on the topic. The former search will have a high recall, retrieving more results; in doing so, the user is unlikely to miss any relevant items. The latter search will have high precision, which refers to retrieving fewer, but relatively dead-on and unerring, results.

\section{Subject Heading Search}

Even a cursory look at the bibliographic data in the field will reveal that many of the titles contain the terms "Fātimids" or "Ismä îlis" with their language variants. A keyword search on one of these terms will retrieve all of the items that contain the term without taking into account the rest of the subject matter. A search can be made more focused by the addition of subject headings to each record.

Subject headings can be general — for example, "castles" and "coinage" or subject-specific — such as "Imamate" (hereditary office or institution of the Imam) and $t a^{\prime} w \bar{i} l .{ }^{17}$ A subject search on the term $t a^{\prime}$ wìl will retrieve all of the items that have been assigned that heading. A record may contain more than one subject heading to describe fully the content of an item. The table below lists more examples of subject-specific headings in this subject area.

\footnotetext{
${ }^{14}$ See Emily A. Largent and Richard T. Snodgrass, "Blind Peer Review by Academic Journals," in Blinding as a Solution to Bias: Strengthening Biomedical Science, Forensic Science, and Law, ed. Christopher T. Robertson and Aaron S. Kesselheim (Boston: Elsevier Academic Press, 2016), 75-95.

${ }^{15}$ For an overview of the "Assassins," see Farhad Daftary, "Assassins," in Encyclopaedia Islamica, 2011, accessed February 20, 2018. http://referenceworks.brillonline.com/browse/encyclopaedia-islamica. The term is pejorative but continues to persist in scholarly and popular discourse including library classification systems. See N. A. Jiwa, 27.

${ }^{16}$ On the Guptiss, see Shafique N. Virani, "Taqiyya and Identity in a South Asian Community," Journal of Asian Studies 70, no. 1 (2011): 99-139.

${ }^{17}$ Examples of works that would be classified under this heading are Diane Steigerwald, "Ismā 'îli Ta'wìl," in The Wiley Blackwell Companion to the Qur'ān, 2nd ed., ed. Andrew Rippin and Jawid Mojaddedi (Hoboken, NJ: John Wiley and Sons, 2017), 463-

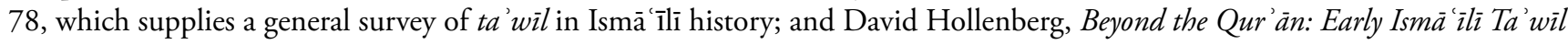
and the Secrets of the Prophets (Columbia: University of South Carolina Press, 2016), which focuses on $t a^{\prime}$ wìl in early Ismā ìli and, in part, Fātimid thought.
} 


\section{Table}

\begin{tabular}{|c|c|}
\hline Personages & Ḥasan-i Șabbāḥ; ${ }^{18}$ Ibn al-Haytam ${ }^{19}$ \\
\hline Places & Manșūriyya; ${ }^{20}$ Tajikistan $^{21}$ \\
\hline Groups & Bohras; ${ }^{22}$ Qarmați ${ }^{23}$ \\
\hline Concepts & $n \bar{u} r{ }^{24}$ waläyd $^{25}$ \\
\hline Institutions & $\begin{array}{l}\text { Aga Khan Development Network (AKDN) }{ }^{26} \\
\text { Jamá }^{\prime} t-k h \bar{a} n a s^{27}\end{array}$ \\
\hline Titles of Works & $\begin{array}{l}\text { Dustūr al-Munajjimīn }{ }^{28} \\
\text { Kalām-i Mawlä }{ }^{29}\end{array}$ \\
\hline
\end{tabular}

The user will also benefit by the addition of an alphabetical subject heading guide that lists all of the subject headings used in the database.

\footnotetext{
${ }^{18}$ On the founder of the Nizārī Ismā ìlī state and da 'wa (summons) in Persia, see Farhad Daftary, "Hasan-i Șabbāḥ,” in Encyclopaedia of Islam, 3rd ed., 2016, accessed February 20, 2018. http://referenceworks.brillonline.com/browse/encyclopaediaof-islam-3; and Carole Hillenbrand, "A Neglected Source on the Life of Hasan-i Sabbah, the Founder of the Nizari 'Assassin' Sect," Iran: Journal of the British Institute of Persian Studies 55, no. 1 (2017): 3-10.

${ }^{19}$ An Ismā 'îlì $d \bar{a}$ ' $\bar{l}$ (summoner) not to be "confused with his much more famous namesake: Ibn al-Haytam the mathematician." See Regula Forster, "Dialogue and Autobiography: Ibn al-Hayțam’s Kitāb al-Munāzarāt," in Il dialogo nella cultura araba: Strutture, funzioni, significati (VIII-XIII secolo), ed. Mirella Cassarino and Antonella Ghersetti (Soveria Mannelli: Rubbettino, 2015), 91.

${ }^{20}$ On the city of Manșūriyya, see Jonathan M. Bloom, Arts of the City Victorious: Islamic Art and Architecture in Fatimid North Africa and Egypt (New Haven: Yale University Press, 2007), 37-42. The city was named after its founder, the third Fātimid Imam Caliph al-Manșūr bi'llāh.

${ }^{21}$ For an overview of the Tajik Ismā 'ìlīs, see Otambek Mastibekov, "Ismā 'îlīs (Tajiks)," in Oxford Islamic Studies Online, 2016, accessed February 20, 2018. http://www.oxfordislamicstudies.com

${ }^{22}$ For an overview of the Bohras, see Tahera Qutbuddin, "Bohras," in Encyclopaedia of Islam, 3rd ed., 2013, accessed February 20, 2018. http://referenceworks.brillonline.com/browse/encyclopaedia-of-islam-3

${ }^{23}$ For an overview of the Qarmațīs, see Ismail K. Poonawala, "Qarāmițah,” in Encyclopedia of Religion, 2nd ed, ed. Lindsay Jones (Detroit: Macmillan Reference USA, 2015), 11: 7542-544.

${ }^{24}$ On the concept of nūr (light) in Ismā ìlīsm, see Mir Baiz Khan, "Chirāgh-i Rōshan: Prophetic Light in the Ismā 'îlī Tradition,” Islamic Studies 52, no. 3/4 (2013), 336-46; and Arzina R. Lalani, "Concept of Light in Ismaili Philosophy," Ishraq 5 (2014): 404-26.

${ }^{25}$ On the concept of walaya (devotion to the Imam), see Hermann Landolt, "Walāyah,” in Encyclopedia of Religion, 2nd ed., ed. Lindsay Jones (Detroit: Macmillan Reference USA, 2005), 14: 9658-660. See further, Elizabeth R. Alexandrin, Walāya in the Fätimid Ismā ìlī Tradition (Albany: State University of New York Press, 2017), 8-16.

${ }^{26}$ On the AKDN, see Aga Khan Development Network, 2018, accessed February 20, 2018. http://www.akdn.org/. See further, Soumen Mukherjee, "Die internationalen Netzwerke des Aga Khan Development Network: Moglichkeiten und Grenzen eines muslimischen Kosmopolitismus," in Bessere Welten: Kosmopolitismus in den Geschichtswissenschaften, ed. Bernhard Gissibl and Isabella Löhr (Frankfurt: Campus Verlag, 2017), 343-72.

${ }^{27}$ Jamā 't-khānas (houses of congregation) are not only Nizārī Ismā ìlī places of prayer but also function as "community centres for lectures, religious instruction, social activities, counseling, and administration.” Tazim R. Kassam and Ali S. Asani, “jamaatkhana," in Encyclopedia of Muslim-American History, ed. Edward E. Curtis (New York: Facts on File, 2010 ), 1: 307. See further, Sharmina Mawani, "Sanctuary for the Soul: The Centrality of the Jamatkhana in Religious Identity Formation," in Perspectives of Female Researchers: Interdisciplinary Approaches to the Study of Gujarati Identities, ed. Sharmina Mawani and Anjoom A. Mukadam (Berlin: Logos Verlag, 2016), 75-97.

${ }^{28}$ On the Dustür al-Munajjimin (The Canon of the Astrologers), see Eva Orthmann and Petra G. Schmidl, eds., Science in the City of Fortune: The Dustūr al-Munajjiminn and its World (Berlin EB-Verlag, 2017), 13-33.

${ }^{29}$ On the Kalām-i Mawlā (The Discourse of Mawlā 'Alì), see Amin Valliani, "Kalām-i Mawlā," Journal of the Pakistan Historical Society 56, no. 3 (2008): 91-103.
} 
Other features that need to be considered are "Sorting/Display/Output Capabilities." ${ }^{30}$ Examples include ranking results by relevance (Sorting); the number of results to be displayed per page (Display); and database support for bibliographic management software programs such as RefWorks or EndNote (Output).

Secondary sources in Ismā î̀ī Studies are written in a multitude of languages, including Albanian, Arabic, Dutch, English, French, German, Gujarati, Hebrew, Hungarian, Italian, Japanese, Persian, Polish, Russian, Serbo-Croat-Bosnian, Sindhi, Spanish, Tajik, Turkish, Urdu, and others. While language diversity is an asset, it can also act as a barrier between the user and the data. A user will easily miss finding items of relevance published in unfamiliar languages. It is, therefore, of prime importance to offer English translations of (at the very least) titles of items in foreign languages.

\section{Metadata}

Metadata is most commonly defined as "data about data," and consists of elements that facilitate resource description and discovery. The following basic citation illustrates how metadata works. It has the author, date, title, publisher place, and publisher(s).

Willey, Peter. Eagle's Nest: Ismaili Castles in Iran and Syria. London: I.B. Tauris in association with The Institute of Ismaili Studies, 2005.

Here is the same resource with additional metadata. The record now includes an ISBN, OCLC Number, and a description. It also includes subject headings, a summary, and table of contents, "rich descriptive information ... [which] drives content discovery." 32 For instance, suppose that a researcher is interested in finding studies on coins from the Alamūt period. ${ }^{33}$ Chances are the researcher would not think that Willey's book is of relevance based on the title. However, reproducing the table of contents ${ }^{34}$ indicates to the researcher that the book includes an appendix on Alamūt coinage. A keyword search on the terms "Alamūt" and "coins" will retrieve this record, and this is an instance of metadata driving content discovery.

Scholarly journal articles have their own particular metadata elements. Here is an example of such a record. ${ }^{35}$

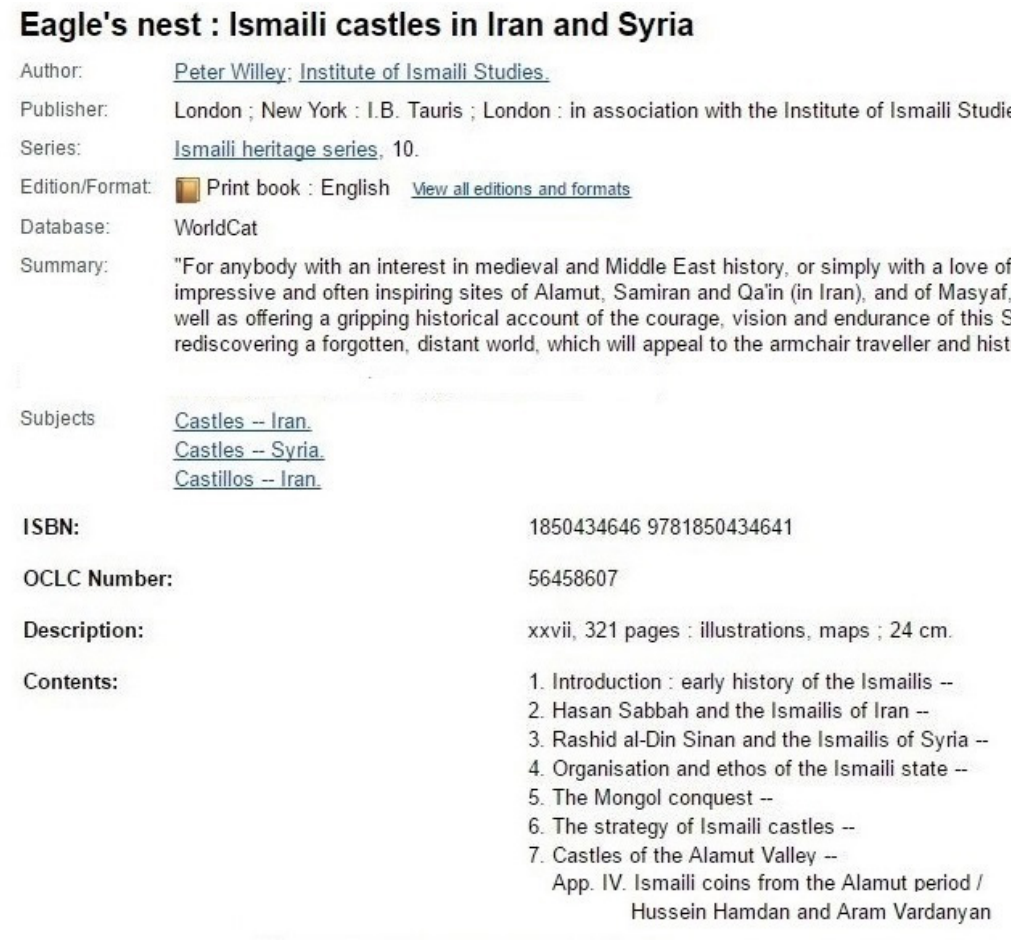

Figure $1^{31}$

\footnotetext{
${ }^{30}$ Bell, 262-63.

${ }^{31}$ Screenshot (C) 2017 OCLC Online Computer Library Center, Inc. Used with permission of OCLC. WorldCat is a registered trademark/service mark of OCLC.

${ }^{32}$ Renée Register, “The Importance of Metadata for E-content," e Content Quarterly 1, no. 1 (2013): 30.

${ }^{33}$ For an overview of the Alamūt period as well as the castle of Alamūt itself, see Sadeq Sajjadi, Enayat Allah Majidi, Farhad Daftary, and Roxane Zand, "Alamūt," in Encyclopaedia Islamica, 2011, accessed February 20, 2018. http://referenceworks. brillonline.com/browse/encyclopaedia-islamica. See further, Hamideh Choubak, "Alamut Castle (Eagle's Nest): Hassan Sabbah Stronghold," International Journal of Humanities 16, no. 2 (2009): 1-29.

${ }^{34}$ The table of contents has been modified from the original to save space.

${ }^{35}$ Screenshot (C) 2017 EBSCO Information Services (EIS). Used with permission of EIS.
} 
Potentially an 'Art Object': Tajik Ismailis' Bāteni and Zāheri Engagement with Their Imam's Image.

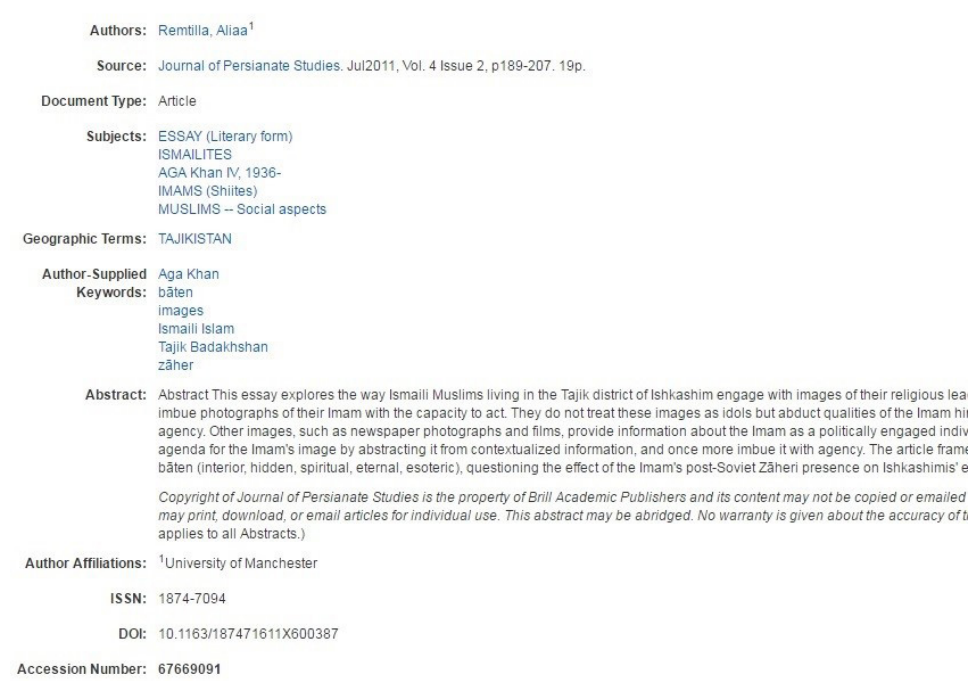

Figure $2^{35}$

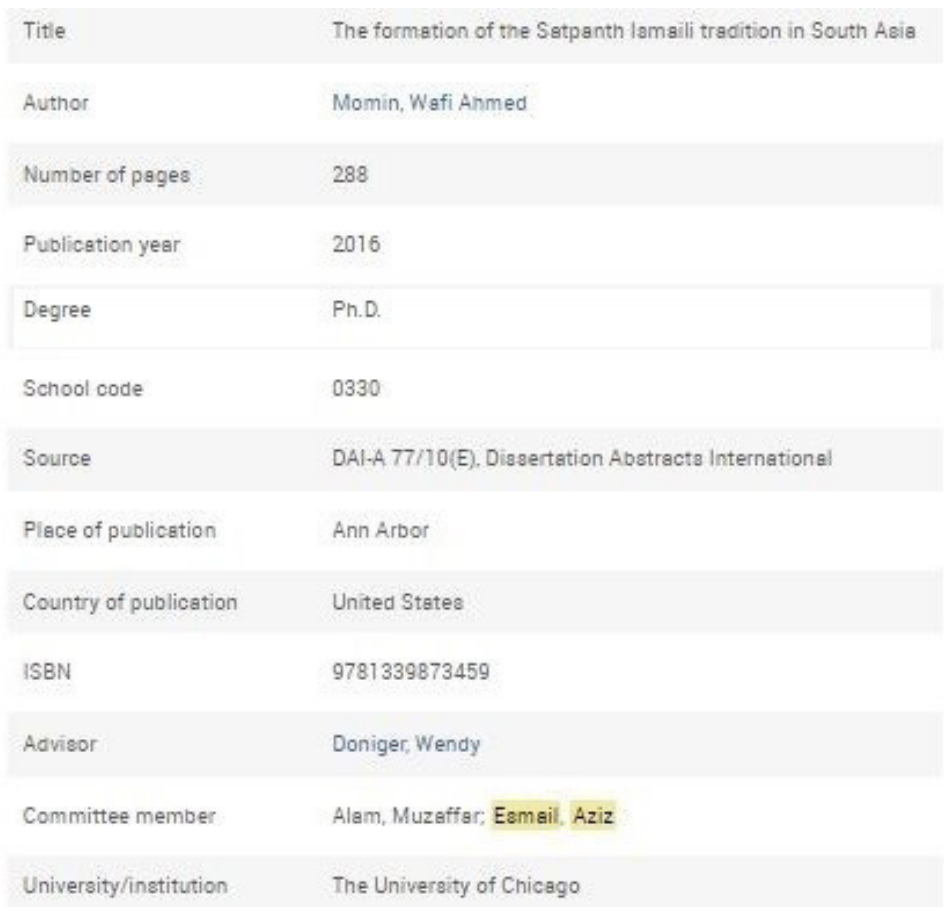

Figure $3^{37}$
Basic metadata includes the author and article title along with the journal title, volume and issue numbers, pages, and date. The record also has an ISSN, DOI, and an EBSCO Accession Number. Rich descriptive metadata consists of subject headings, an author-supplied abstract, and keywords also supplied by the author. The keywords include the terms zähir (exoteric) and bätin (esoteric), which are not listed as subject headings. The insertion of these subject-specific keywords in the record increases the findability of the item.

The importance of a research abstract, written either by the author or abstractor, cannot be understated. If the abstract cannot be reproduced, the record can contain a link to the abstract if it is available online. The record must also contain a link to the full text (if available), and whether it is accessible on fee-and/or free-based sites. The end goal of linkage is to increase efficiency by not having the user search again, externally, for the abstract or full text.

The addition of metadata can also help fuel serendipitous searching, the accidental discovery of a source of relevance while searching for something else. Envisage a researcher who is aware of the following dissertation (i.e., a known item) and wants to determine if the author has written more on the topic of Satpanth (the true path): ${ }^{36}$

Esmail, Aziz. "Satpanth Ismailism and Modern Changes within it, with Special Reference to East Africa." PhD diss., University of Edinburgh, 1972.

A search on the author's name as a keyword will retrieve not only this dissertation but also the dissertation by Wafi Momin (seen at left).

The basic metadata consists of the author's name, dissertation date and title, degree type, and institution. As with the previous example, this record contains subject headings, an authorsupplied abstract and keywords (not shown here). The record also lists the dissertation advisor and doctoral committee members including the author in question (Aziz Esmail). A look at the title indicates that Momin's dissertation is on the same topic (Satpanth) and is in all probability of high relevance to the researcher. This serendipitous discovery would not have occurred if the researcher had restricted the initial search to the author field. This instance is contrary

\footnotetext{
${ }^{36}$ For a succinct summary of the Satpanth da'wa, see Ali S. Asani, "Isma ilism: Isma ilism in Ginān Literature," in Encyclopaedia Iranica, 2007. Accessed February 20, 2018. http://www.iranicaonline.org

37 Screenshot (C) 2017 ProQuest Limited Liability Company (LLC). Used with permission of ProQuest LLC.
} 
to Alemu and Stevens's insistence that "library databases ... are very unlikely to offer the possibility of accidentally pertinent search results." ${ }^{38}$

Online scholarly sources have their own distinctive metadata in addition to the elements discussed thus far. The following sample record for an online encyclopedia entry illustrates the metadata that is common to both print and online items, as well as some of the additional metadata required. The elements presented here conform to the Dublin Core Metadata Element Set [Version 1.1]. ${ }^{39}$

Common metadata includes the author, entry and encyclopedia title, publisher, publisher place, publication date, and language. Additional metadata includes the date updated, rights management, and URL identifier. It is important to realize that these and other online metadata elements are dynamic in nature. They can change over time, some more rapidly than others. Records for online documents need to be monitored regularly

\begin{tabular}{|c|c|}
\hline Author/Creator: & Baffioni. Carmela \\
\hline Title: & Ilkhwân al-Safấ: \\
\hline Source: & Stanford Encyclopedia of Philosophy \\
\hline Contributor: & Zalta, Edward N. (Editor) \\
\hline Publisher: & Metaphysics Research Lab \\
\hline Publisher Place: & Stanford, CA \\
\hline Language: & English \\
\hline Type: & Text \\
\hline Format: & text $/ \mathrm{html}$ \\
\hline Subjects: & $\begin{array}{l}\text { Ilkhwan al-Safa, Brethren of Purity } \\
\text { Philosophy, Encyclopedias }\end{array}$ \\
\hline Date Created: & $2008-04-22$ \\
\hline Date Updated: & $2016-07-08$ \\
\hline Identifier: & \\
\hline https://plato.stanford & /archives/fall2016/entries/ikhwan-al-safa/ \\
\hline Description: & \\
\hline $\begin{array}{l}\text { Encyclopedia entry on } \\
\text { of the Stanford Encyc }\end{array}$ & $\begin{array}{l}\text { Ikhwan al-Safa/Brethren of Purity from the online version } \\
\text { dia of Philosophy. }\end{array}$ \\
\hline Coverage: & gth-1oth Century \\
\hline Rights Management: & https://plato.stanford.edu/info.html \\
\hline Relation: & http://www.iep.utm.edu/ikhwan-al-safa/ \\
\hline
\end{tabular}

Figure $4^{40}$ to ensure the completeness and accuracy of the metadata.

The encyclopedia entry is on the Ikhwān al-Ṣafä' whose name is most commonly translated as the "Brethren of Purity." However, this translation is not provided in the title of the article. A search on the phrase "Brethren of Purity" will not retrieve this particular record without additional metadata. The online illustration contains a description element which functions similar to an abstract, where the translation is given. Hence, a keyword search will retrieve this entry as will a subject search due to the fact that the phrase "Brethren of Purity" is assigned as one of the subjects. As with metadata for print sources, some records for online sources may contain the most basic metadata while others may be more detailed.

\section{Exclusivity}

The categories of resources of the first search method identified in the Addenda resemble the description of resources harvested by Discovery Services including OPACs, databases, and digital libraries. The question then arises: why create an Ismā ìlì Studies database when a Discovery Service performs the same task?

As mentioned earlier, the Addenda supplies a representative list of general and subject-specific resources consulted during its compilation. Part of the answer to that question is that Discovery Services, though quite thorough, do not index (or rather pre-index) all of these resources. Many of the resources searched inevitably retrieved duplicates, but also unique and undiscovered bibliographic data. Google Scholar, which has been used as a substitute for Discovery Services ${ }^{41}$ must also be used in conjunction with other resources in order to maximize comprehensiveness and completeness.

\footnotetext{
${ }^{38}$ Getaneh Alemu and Brett Stevens, An Emergent Theory of Digital Library Metadata: Enrich then Filter (Waltham, MA: Chandos Publishing, 2015), 81.

${ }^{39}$ Dublin Core Metadata Element Set. 2012, accessed February 20, 2018. http://dublincore.org/documents/dces/

${ }^{40}$ Logo (C) 2017 The Stanford Encyclopedia of Philosophy (SEP). Used with permission of SEP.

${ }^{41}$ Piet De Keyser, "Discovery Services, the Next Tool Libraries Must Have, or... Should Discard?" in E-Discovery Tools and Applications in Modern Libraries, ed. Egbert De Smet and Sangeeta N. Dhamdhere (Hershey, PA: Information Science Reference, 2016), 56-65.
} 
There are also differences in the data harvested across Discovery Services resulting in the exclusion of items. It will be the user who will suffer by missing materials in a field that places a high premium on every study, owing to the overall paucity of research in Ismā ìlī Studies.

In addition, the size of the data contained in Discovery Services and Google Scholar is colossal and continues to expand at an unprecedented rate. Research indicates "that, unfortunately, the larger a database is the harder it is to locate information in it, no matter how good the search engine or how expert the searcher." 42 For example, a keyword search on the term $t a^{\prime}$ 'wil in Discovery Services/Google Scholar is bound to retrieve irrelevant results on the Andersen-Tawil Syndrome (ATS). By searching in a subject-specific database, the user is guaranteed to retrieve results on the right kind of $t a^{\prime} w i l$.

Another question that arises is why not use a subject-specific resource already in place such as Index Islamicus? Besides its limitation of coverage in European languages only, the scope of that database is ambitious, attempting to cover all of the subfields and specialities in Islamic Studies. Its content is relatively large, containing over 500,000 records at the time of this writing. Even while allowing for the widest margin of error, the number of secondary sources cited in the existing bibliographies for Ismā '̇ili Studies does not exceed 5,000 entries. Searching for sources in a database of 5,000 records is more efficient and effective than searching a database 100 times its size.

For example, a keyword search on the term "Imamate" in Index Islamicus will retrieve quite a number of results as the concept of Imamate is not confined to Ismā îlīism. ${ }^{43}$ An Ismā 'îlì Studies database will eliminate most irrelevant results; in this instance, that being the concept of the Imamate in other schools of thought. It will also reduce the number of false drops, which are sources that are retrieved by search terms but where the terms are not used as intended. For example, a keyword search in Index Islamicus on the terms "Fāṭimid" and "Egypt" will retrieve all of the individual records of the Egypt and Syria in the Fatimid, Ayyubid and Mamluk Eras colloquia series even if they are on the Ayyübids or Mamlūks.

The University of Chicago Library in partnership with the Middle East Documentation Center (MEDOC) supports the Mamluk Bibliography Online. ${ }^{44}$ This is a resource dedicated exclusively to Mamlūk Studies, indicating that the coverage of other databases in this field is found to be inadequate. Shainool Jiwa maintains that the Fātimids remain relatively understudied in comparison to the successor dynasties in Egypt, such as the Ayyūbids and the Mamlūks. ${ }^{45}$ This makes having a single database that aggregates all of the available data on the Fățimids (albeit as a subfield) all the more essential.

Furthermore, having a subject-specific database offers the flexibility to customize subject headings. The term Satpanth alluded to earlier designates a major phase in Ismā îlīsm which has been, and continues to be, marginalized in Ismā îli Studies. ${ }^{46}$ This is also reflected in the indexing of items on the Satpanth, where the term itself as a subject heading is absent from controlled vocabulary lists such as the Library of Congress Subject Headings (LCSH), OCLC descriptors, and Index Islamicus (as of yet). While these lists are undeniably useful and can be drawn upon to assign general and, to a certain extent, subject-specific headings, creating customized subject headings will allow for greater specificity.

However, it is not enough to assign more precise subject headings to a bibliographic record without taking into consideration indexing consistency. This is demonstrated through the use of the Ismā îli gināns ${ }^{47}$ which have their origins in the Satpanth period.

\footnotetext{
${ }^{42}$ Donna L. O’Malley, “A Survey of Scholarly Literature Databases for Clinical Laboratory Science," Clinical Laboratory Science 21, no. 1 (2008): 54.

${ }^{43}$ For the concept of the Imamate in Ismā' îlissm in particular, see Azim A. Nanji, "Isma 'ilism: The Imamate in Isma 'ilism," in Encyclopaedia Iranica, 2007, accessed February 20, 2018. http://www.iranicaonline.org

${ }^{44}$ Mamluk Bibliography Online. 2013, accessed February 20, 2018. http://mamluk.lib.uchicago.edu/

${ }^{45}$ Shainool Jiwa, e-mail message to author, April 17, 2017.

${ }^{46}$ Tazim R. Kassam, "The Living Tradition of Ismaili Ginans: Negotiating Cultures in Poetry and Performance," in Lines in Water: Religious Boundaries in South Asia, ed. Eliza F. Kent and Tazim R. Kassam (Syracuse, NY: Syracuse University Press, 2013), 136.

${ }^{47}$ On the gināns, see Asani, "Isma' ilism." It is worth noting that there are a number of online resources dedicated exclusively to ginānic studies, which is a subfield of Ismā 'îli Studies, but none that covers the entire field. Representative resources include Pyarali Jiwa, Library of Ginans and Granths, The Association for the Study of Ginans, 2011, accessed February 20, 2018. http:// ginans.org/download.php; and Karim Tharani, Ginan Central, University of Saskatchewan Library, 2018, accessed February 20, 2018. http://ginans.usask.cal
} 
The Ginans are hymns, religious lyrics, which have for long been a central part of the religious life of the Indian Nizari Ismaili community (known as Khojas), and of which they continue to form the living religious tradition. ... The term "Ginan" is believed to derive from the Sanskrit jnän, an abstract noun, which may be variously rendered as "knowledge," "wisdom" or "cognition" (reminiscent, to some extent, of the Greek gnosis). In the Indian Ismaili tradition it has come to refer to the individual hymns, and is thus treated as a countable name. ... The Ginans are a vast corpus consisting of several hundred (indeed by some estimates over a thousand) hymns. ${ }^{48}$

Different authors have offered different renderings of the term ginān. These include canticles, compositions, hymns, literature, liturgies, lyrics, music, odes, poems, poetry, rhymes, songs, texts, verses, and so on. These terms are usually preceded by qualifiers such as devotional, esoterical, gnostical, holy, mystical, religious, sacred, spiritual, and the like.

After having established that an item is about the gināns, an indexer needs to first select a subject term (let us say hymns) and assign it to the bibliographic record. This is in addition to assigning the term ginān to the record and is of particular benefit to a user who is not familiar with the terminology. The indexer then needs to use the same preferred terms (i.e., hymns and gināns) in indexing any subsequent items on the topic. This is referred to as intra-indexer consistency. Interindexing consistency refers to the fact that a different indexer will use the same preferred terms of hymns and gināns in indexing further items on the topic. Both intra-and inter-indexing consistencies ${ }^{49}$ are paramount in facilitating effective searching by subject headings.

The term ginān is a subject heading in both LCSH and OCLC descriptors. Unfortunately, it is applied haphazardly and inconsistently at the time of this writing. Consequently, a subject heading search on the term ginān will not retrieve all of the relevant items on the topic. The problem is compounded by the fact that different items on the ginanns are denoted by different subject headings such as the renderings listed in the paragraph before the preceding one.

An Ismā î̀i Studies database will ensure that subject headings including gināns will be assigned uniformly and consistently. This will also pertain to customized subject-specific headings, some examples of which are identified in the table above. Not surprisingly, research shows that subject-specific database searches are more comprehensive and relevant than general database searches, presumably due to subject-specific indexing and content. ${ }^{50}$

\section{Timeline}

The creation of the database can be divided into three main phases: (1) Secure Funding; (2) Database Design; and (3) Content Management.

\section{Phase 1}

Ultimately, the creation and maintenance of the database needs sufficient and continued financial support from individuals and institutions, at both private and public levels. Partial or intermittent funding may result in having to forego some of the features and settle for a basic relational database. After all, it is more prudent and beneficial to have a database with limited capabilities than none at all.

\section{Phase 2}

Once funding is secured, a database designer will need to build the database according to the specifications outlined above. There are further decisions to be made in consultation with the designer. One area in particular is the user's experience of interaction with the database. The questions to be asked range from: "What will the font and colours of the interface be?" to "Will it consist of a single 'Google Model' search box or will the search page display additional information?" Many usability decisions will be determined based on the amount of funding available. Usability is not

\footnotetext{
${ }^{48}$ Aziz Esmail, A Scent of Sandalwood: Indo-Ismaili Religious Lyrics (Ginans) Volume 1 (Richmond, Surrey, UK: Curzon, 2002), $2-3$.

${ }^{49}$ M.S. Ramalingam, Library Cataloguing and Classification Systems (Delhi: Kalpaz Publications, 2000), $295-96$.

${ }^{50}$ Helen Aveyard, Pam Sharp, and Mary Woolliams, A Beginner's Guide to Critical Thinking and Writing in Health and Social Care, 2nd ed. (Maidenhead, UK: Open University Press, 2015), 47.
} 
detailed here in view of the fact that it "is open to both a subjective and objective evaluation." 51

Phase 3

Tasks that must be performed by professionally trained staff while allowing for some degree of overlap are identified below.

\section{Bibliographic Verification}

Verify all the bibliographic information contained in each entry of the existing bibliographies, correct all the errors, and eliminate duplicates, i.e., items cited in both Tajdin and Daftary. Bibliographic verification should ideally be performed by personally examining each individual document. ${ }^{52}$ This also applies to entries created for new content entered into the database.

\section{Subject Indexing and Metadata}

Create and assign subject headings for each entry. Add rich descriptive metadata as items cited in the existing bibliographies contain only the most basic elements. Both subject headings and metadata can be input retroactively once the database is operational.

\section{Updating and Editing}

Search for new content from 2004 to the present (including omissions from previous years). Create and assign subject headings and metadata for each entry. Perform ongoing editing of records ensuring the content is current, consistent, and complete.

\section{Data Rekeying}

Rekey all of the data from the existing bibliographies and new content into the database.

\section{Conclusion}

This paper has made a case for the imperative need to build an online database dedicated exclusively to Ismā îli Studies, to further research in the field. Its scope is intentionally broad to include even the most outlier studies. ${ }^{53}$ Data extracted from the existing bibliographies and data originating from updates will still need to be vetted to verify that individual items fall within the purview of the database. The search features outlined herein have a common objective, to retrieve precise and particularly required search results. The role of subject indexing and metadata is fundamental in enhancing the searchability of each record. Also fundamental is the necessity of exclusivity in order to optimize the efficiency and effectiveness of the database. Given the fact that an online searchable database dedicated exclusively to Ismā îli Studies is a natural and essential progression in the field, it is the present bibliographer's hope that the Addenda will be the last published bibliography of secondary sources in print form.

\section{Acknowledgements}

I am grateful to Professor Karim H. Karim for giving me the opportunity to make a presentation at the 2nd Ismaili Studies Conference (ISC), "Mapping a Pluralist Space in Ismaili Studies," Carleton Centre for the Study of Islam, Ottawa, Canada (March 9-10, 2017). I am also grateful to all of the altruistic individuals who provided me with valuable feedback on that presentation, as well as on this resulting paper including the journal's anonymous reviewers. Their feedback has substantially improved the quality of this paper while all deficiencies are my own responsibility. I wish

\footnotetext{
${ }^{51}$ Bell, 260.

52 James H. Sweetland, "Errors in Bibliographic Citations: A Continuing Problem," The Library Quarterly: Information, Community, Policy 59, no. 4 (1989): 291.

${ }^{53}$ Examples include M.E. Soltan, "Environmental Chemical Study on the Marsh of Fatimid Cemetery at Aswan City, Egypt," Journal of Environmental Sciences 14, no. 4 (2002): 464-73; and Barbara Czaja-Szewczak, "Conservation of a Fatimid Shawl from the Naqlun Cemetery," Polish Archaeology in the Mediterranean 19 (2010): 248-50.
} 
to thank the following vendors for giving me permission to reproduce screenshots of their databases: OCLC Online Computer Library Center, Inc. (Fig. 1); EBSCO Information Services (Fig. 2); and ProQuest LLC (Fig. 3). I also wish to thank The Stanford Encyclopedia of Philosophy (SEP) for granting permission to use their logo (Fig. 4). This work is dedicated to my wife, Nadia, for her unconditional support and belief in me.

\section{Bibliography}

Aga Khan Development Network. 2018. Accessed February 20, 2018. http://www.akdn.org/

Alemu, Getaneh, and Brett Stevens. An Emergent Theory of Digital Library Metadata: Enrich then Filter. Waltham, MA: Chandos Publishing, 2015.

Alexandrin, Elizabeth R. Walāya in the Fätimid Ismā ìlı̀ Tradition. Albany: State University of New York Press, 2017.

Andani, Khalil. "A Survey of Ismaili Studies Part 1: Early Ismailism and Fatimid Ismailism." Religion Compass 10, no. 8 (2016): 191-206.

. "A Survey of Ismaili Studies Part 2: Post-Fatimid and Modern Ismailism." Religion Compass 10, no. 11 (2016): 269-82.

Arastu, Tasneem. “A Dawoodi Bohra Woman’s Experience of Arranged Marriage.” Master's thesis, Michigan School of Professional Psychology, 2009.

Asani, Ali S. "Isma ilism: Isma ilism in Ginān Literature." In Encyclopaedia Iranica. 2007. Accessed February 20, 2018. http://www.iranicaonline.org

Aveyard, Helen, Pam Sharp, and Mary Woolliams. A Beginner's Guide to Critical Thinking and Writing in Health and Social Care. 2nd ed. Maidenhead, UK: Open University Press, 2015.

Bell, Suzanne S. Librarian's Guide to Online Searching: Cultivating Database Skills for Research and Instruction. 4th ed. Santa Barbara, CA: Libraries Unlimited, 2015.

Bloom, Jonathan M. Arts of the City Victorious: Islamic Art and Architecture in Fatimid North Africa and Egypt. New Haven: Yale University Press, 2007.

Choubak, Hamideh. “Alamut Castle (Eagle's Nest): Hassan Sabbah Stronghold.” International Journal of Humanities 16, no. 2 (2009): 1-29.

Czaja-Szewczak, Barbara. "Conservation of a Fatimid Shawl from the Naqlun Cemetery." Polish Archaeology in the Mediterranean 19 (2010): 248-50.

Daftary, Farhad. Ismà ìlì Literature: A Bibliography of Sources and Studies. London: I.B. Tauris in association with The Institute of Ismaili Studies, 2004.

_. “Assassins.” In Encyclopaedia Islamica. 2011. Accessed February 20, 2018. http://referenceworks.brillonline. $\underline{\text { com/browse/encyclopaedia-islamica }}$

. “Ḥasan-i Șabbāh.” In Encyclopaedia of Islam, 3rd ed., 2016. Accessed February 20, 2018. http://referenceworks. brillonline.com/browse/encyclopaedia-of-islam-3

De Keyser, Piet. “Discovery Services, the Next Tool Libraries Must Have, or... Should Discard?” In E-Discovery Tools and Applications in Modern Libraries, ed. Egbert De Smet and Sangeeta N. Dhamdhere. Hershey, PA: Information Science Reference, 2016, 56-65.

“Dublin Core Metadata Element Set." 2012. The Dublin Core Metadata Initiative (DCMI). Accessed February 20, 2018. http://dublincore.org/documents/dces/

Esmail, Aziz. A Scent of Sandalwood: Indo-Ismaili Religious Lyrics (Ginans) Volume 1. Richmond, Surrey, UK: Curzon, 2002.

Forster, Regula. "Dialogue and Autobiography: Ibn al-Hayțam's Kitāb al-Munāzarāāt. In Il dialogo nella cultura 
araba: Strutture, funzioni, significati (VIII-XIII secolo), ed. Mirella Cassarino and Antonella Ghersetti (Soveria Mannelli: Rubbettino, Italy, 2015), 91-105.

Hauziński, Jerzy. “On the Titles of the Ismā îlī-Nizārī Leaders in the Alamūt Period.” Folia Orientalia 49 (2012): 233-39.

Hetherington, Carol. "Setting the Record Straight: Bibliography and Australian Literature." Australian Literary Studies 21, no. 2 (2003): 198-208.

Hillenbrand, Carole. "A Neglected Source on the Life of Hasan-i Sabbah, the Founder of the Nizari 'Assassin' Sect." Iran: Journal of the British Institute of Persian Studies 55, no. 1 (2017): 3-10.

Hollenberg, David. Beyond the Qur'àn: Early Ismà 'ìlī Ta' wìl and the Secrets of the Prophets. Columbia: University of South Carolina Press, 2016.

Jiwa, Nawazali A. "Addenda to Secondary Sources in Ismā' îlī Studies: The Case of the Omissions." MELA Notes: Journal of Middle Eastern Librarianship 86 (2013): 20-101.

Jiwa, Pyarali. Library of Ginans and Granths. The Association for the Study of Ginans. 2011. Accessed February 20, 2018. http://ginans.org/download.php

Kassam, Tazim R. "The Living Tradition of Ismaili Ginans: Negotiating Cultures in Poetry and Performance." In Lines in Water: Religious Boundaries in South Asia, ed. Eliza F. Kent and Tazim R. Kassam. Syracuse, NY: Syracuse University Press, 2013, 125-58.

Kassam, Tazim R., and Ali S. Asani. “jamaatkhana." In Encyclopedia of Muslim-American History, ed. Edward E. Curtis. New York: Facts on File, 2010, 1: 306-7.

Khan, Mir Baiz. "Chirägh-i Rōshan: Prophetic Light in the Ismā ìlì Tradition.” Islamic Studies 52, no. 3/4 (2013): 327-56.

Lalani, Arzina R. "Concept of Light in Ismaili Philosophy." Ishraq 5 (2014): 404-26.

Landolt, Hermann. "Walāyah.” In Encyclopedia of Religion. 2nd ed., ed. Lindsay Jones. Detroit: Macmillan Reference USA, 2005, 14: 9656-62.

Largent, Emily A., and Richard T. Snodgrass. "Blind Peer Review by Academic Journals." In Blinding as a Solution to Bias: Strengthening Biomedical Science, Forensic Science, and Law, ed. Christopher T. Robertson and Aaron S. Kesselheim. Boston: Elsevier Academic Press, 2016, 75-95.

Mamluk Bibliography Online. 2013. Accessed February 20, 2018. http://mamluk.lib.uchicago.edu/

Mastibekov, Otambek. "Ismā 'ilīs (Tajiks)." In Oxford Islamic Studies Online. 2016. Accessed February 20, 2018. http://www.oxfordislamicstudies.com

Mawani, Sharmina. "Sanctuary for the Soul: The Centrality of the Jamatkhana in Religious Identity Formation." In Perspectives of Female Researchers: Interdisciplinary Approaches to the Study of Gujarati Identities, ed.

Sharmina Mawani and Anjoom A. Mukadam. Berlin: Logos Verlag, 2016, 75-97.

Momen, Moojan. Review of Ismaili Literature: A Bibliography of Sources and Studies, by Farhad Daftary. Islam and Christian-Muslim Relations 16, no. 4 (2005): 433-34.

Mukherjee, Soumen. "Die internationalen Netzwerke des Aga Khan Development Network: Moglichkeiten und Grenzen eines muslimischen Kosmopolitismus." In Bessere Welten: Kosmopolitismus in den Geschichtswissenschaften, ed. Bernhard Gissibl and Isabella Löhr. Frankfurt: Campus Verlag, 2017, 343-72.

Nanji, Azim A. "Isma 'ilism: The Imamate in Isma ilism." In Encyclopaedia Iranica. 2007. Accessed February 20, 2018. http://www.iranicaonline.org

O’Malley, Donna L. “A Survey of Scholarly Literature Databases for Clinical Laboratory Science.” Clinical Laboratory Science 21, no. 1 (2008): 49-57. 
Orthmann, Eva, and Petra G. Schmidl, eds. Science in the City of Fortune: The Dustūr al-Munajjimin and its World. Berlin EB-Verlag, 2017.

Poonawala, Ismail K. “Qarāmițah.” In Encyclopedia of Religion. 2nd ed., ed. Lindsay Jones. Detroit: Macmillan Reference USA, 2015, 11: 7542-44.

Qutbuddin, Tahera. "Bohras." In Encyclopaedia of Islam, 3rd ed., 2013. Accessed February 20, 2018. http:// referenceworks.brillonline.com/browse/encyclopaedia-of-islam-3

Ramalingam, M. S. Library Cataloguing and Classification Systems. Delhi: Kalpaz Publications, 2000.

Register, Renée. “The Importance of Metadata for E-content.” eContent Quarterly 1, no. 1 (2013): 30-44.

Sabzaali, Saira Jamal. "Leaving My Mother's House: Khoja Ismaili Women and University." PhD diss., Institute of Transpersonal Psychology, 2007.

Sajjadi, Sadeq, Enayat Allah Majidi, Farhad Daftary, and Roxane Zand (tr.). "Alamūt." In Encyclopaedia Islamica. 2011. Accessed February 20, 2018. http://referenceworks.brillonline.com/browse/encyclopaedia-islamica

Soltan, M.E. "Environmental Chemical Study on the Marsh of Fatimid Cemetery at Aswan City, Egypt." Journal of Environmental Sciences 14, no. 4 (2002): 464-73.

Stebbins, Leslie F. Student Guide to Research in the Digital Age: How to Locate and Evaluate Information Sources. Westport, CT: Libraries Unlimited, 2006.

Steigerwald, Diane. "Ismā ìlì Ta'wīl." In The Wiley Blackwell Companion to the Qur'än. 2nd ed., ed. Andrew Rippin and Jawid Mojaddedi. Hoboken, NJ: John Wiley and Sons, 2017, 463-78.

Sweetland, James H. "Errors in Bibliographic Citations: A Continuing Problem." The Library Quarterly: Information, Community, Policy 59, no. 4 (1989): 291-304.

Tajdin, Nagib. A Bibliography of Ismailism. Delmar, New York: Caravan Books, 1985.

Tharani, Karim. Ginan Central. University of Saskatchewan Library. 2018. Accessed February 20, 2018. http:// ginans.usask.cal

Valliani, Amin. “Kalām-i Mawlā.” Journal of the Pakistan Historical Society 56, no. 3 (2008): 91-103.

Virani, Shafique N. "Taqiyya and Identity in a South Asian Community." Journal of Asian Studies 70, no. 1 (2011): 99-139. 